\title{
PENGARUH BESARANNYA KOMPENSASI DAN DISIPLIN KERJA TERHADAP KINERJA KARYAWAN
}

\author{
Nurdin $^{1}$, Hardian Musrsito ${ }^{2}$ Munzir $^{3}$ \\ ${ }^{1}$ Program Studi Pendidikan Bahasa Indonesia, ${ }^{2,3}$ Program Studi Pendidikan Ekonomi \\ Universitas Indraprasta PGRI Jakarta \\ dr.Nurdin3067@yahoo.com; ianmursito@gmail.com; mun.zier74@gmail.com
}

Diterima: 30 Januari 2020; Direvisi: 29 Maret 2020; dipublikasikan: 30 April 2020

\begin{abstract}
This study aims to determine the compensation and working discipline besaranya on employee performance. Methods The study is a survey research. Subjects of this study as many as 50 employees were taken randomly at PT. Lifes Good in Jakarta. Data was collected by questionnaires using Likert skla. The validity of the data obtained with the validity and reliability, all data has a normal distribution. The results showed that the compensation to give a significant influence on employee performance. Likewise, work discipline gives a significant influence on employee performance. The coefficient of determination $(R) 2$ is the compensation and working discipline has a strong relationship to employee performance.
\end{abstract}

Keywords: Compensation, Discipline, Performance

\begin{abstract}
ABSTRAK
Penelitian ini bertujuan untuk mengetahui besaranya kompensasi dan disiplin kerja terhadap kinerja karyawan. Metode Penelitian merupakan penelitian survei. Subjek penelitian ini sebanyak 50 orang karyawan diambil secara acak di PT.Lifes Good di Jakarta .Data dikumpulkan dengan instrumen angket menggunakan skla likert. Keabsahan data diperoleh dengan uji validitas dan reliabilitas, semua data memiliki distribusi normal.Hasil penelitian menunjukkan bahwa kompensasi memberi pengaruh yang signifikan terhadap kinerja karyawan. Begitu juga disiplin kerja memberi pengaruh yang signifikan terhadap kinerja karyawan. Koefisien determinasi $(\mathrm{R})^{2}$ adalah kompensasi dan disiplin kerja mempunyai hubungan yang kuat terhadap kinerja karyawan.
\end{abstract}

Kata Kunci : Kompensasi, Disiplin, Kinerja 


\section{PENDAHULUAN}

Sumber daya manusia sangat penting dimiliki perusahaan, salah satu diantaranya adalah manusia perlu mempunyai kualitas yang tinggi, dengan sumber daya manusia yang tinggi maka mereka dapat melaksanakan tugasnya dengan baik, sehingga perusahaan akan bisa berkembang, kegagalan suatu organisasi atau perusahaan dapat ditentukan melalui sumberdaya manusianya. Dimana pada dasarnya hubungan yang terjadi adalah hubungan yang saling menguntungkan bagi perusahaan dan karyawan. Karyawan di suatu perusahaan memiliki kualitas yang berbeda beda untuk itu perlu diberikan tugas sesuai dengan keahliannya supaya dapat bekerja dengan baik.

Faktor kepemimpinan juga mempengaruhi kinerja karyawan, artinya jika seorang pemimpin dapat menguasai teknik motivasi dengan baik, yaitu melakukan motivasi dengan bijaksana, arif, dan penuh kewibawaan, sehingga bawahan akan merasa segan pada pimpinannya dan akan berusaha bekerja sesuai dengan tugas dan tanggung jawabnya. Kondisi ini akan mempengaruhi tinggi rendahnya motivasi seseorang dalam bekerja yang pada akhirnya akan berpengaruh pada kinerjanya. Pendapat Litkert dikutip oleh Siagian (2003:17) gaya kepemimpinan dapat diketahui dari : kepemimpinan yang dijalankan, kebiasaan yang dilakukan dalam memotivasi, berkomunikasi, berinteraksi, caranya mengambil keputusan, menetapkan tujuan dan melakukan kontrol.

Tenaga kerja merupakan aset utama perusahaan yang menjadi perencana serta pelaku aktivitas yang aktif dalam perusahaan. Dimana mereka dituntut untuk dapat bekerja lebih disiplin dalam melaksanakan tugas yang telah diberikan kepadanya, untuk itu mereka harus mempunyai rasa tanggung jawab terhadap tugas yang telah diberikan kepadanya, sehingga tugas dapat dikerjakan secara efektif dan efisien. Untuk itu yang menjadi pokok perhatian dalam penelitian ini adalah bagaiman seorang pemimpin dapat memotivasi karyawan dapat bekerja secara disiplin untuk dapat meningkatkan kinerjanya.

\section{Kinerja Karyawan}

Menurut Whitmore (1997:104) kinerja sebagai perilaku menunjuk pada suatu aktifitas yang secara langsung maupun tidak langsung bisa diamati oleh orang lain . Sedangkan Guritno (2005: 63-74), menyatakan bahwa kinerja merupakan perbandingan hasil kerja yang dicapai oleh karyawan dengan standar yang telah ditentukan. Menurut Saladin (1999: 37) kinerja karyawan adalah hasil kerja secara kualitas dan kuantitas yang dicapai oleh seorang karyawan dalam melaksanakan tugasnya sesuai dengan tanggung jawab yang diberikan kepadanya. Selanjutnya penilaian prestasi suatu proses yang digunakan pimpinan untuk menentukan apakah seorang karyawan melakukan pekerjaannya sesuai dengan tugas dan tanggung jawabnya. Menurut Hersey dan Blanchard (2000: 181) menyatakan bahwa kinerja sebagai hasil yang telah dicapi karyawan dengan menggunakan alat. Hal tesebut mengambarkan bahwa kinerja karyawan tidak terlepas dari alat yang digunakan, dengan menggunakan alat yang tepat, maka kinerja karyawan menjadi lebih baik.

Menurut Umar (1999:14) kinerja merupakan hasil yang dicapai seseorang menurut ukuran yang berlaku untuk pekerjaan yang bersangkutan. Menurut Suprihanto (2000:55) kinerja merupakan hasil proses manjemen yang dirancang menghubungkan tujuan organisasi dengan kepentingan individu pegawai dengan tujuan organisasi.

Sedangkan Hasibuan (2001:34) mengemukakan kinerja adalah suatu hasil kerja yang dicapai seseorang dalam melaksanakan tugas - tuigas yang dibebankan kepadanya yang didasarkan atas kecakapan, pengalaman dan kesungguhan sasuai waktu. Mathis dan Jackson (2002:78) mengemukakan bahwa kinerja pada dasarnya individu yang memiliki kinerja yang tinggi dan memiliki beberapa karakteristik yaitu diantaranya : (a) berorientasi pada prestasi, (b) memiliki percaya diri, (c) pengendalian diri, (d) dan kompetensi. 
Cushway (2002:135) berpendapat bahwa ukuran kinerja karyawan dapat disebutkan beberapa hal berikut ini :(1). Quantity of Work yaitu jumlah kerja yang dilakukan dalam suatu periode yang ditentukan. (2). Quality of Work yaitu kualitas kerja yang dicapai berdasarkan syarat - syarat kesesuaian dan kesiapannya. (3). Job knowledgeyaitu luasnya pengetahuan mengenai pekerjaan dan keterampilannya. (4). Creativenessyaitu keaslian gagasan - gagasan yang dimunculkan dan tindakan tindakan untuk menyelesaikan persoalan - persoalan yang timbul. (5). Cooperation: kesediaan untuk bekerja sama dengan orang lain atau sesama anggota organisasi. (6). Depandabilityyaitu kesadaran untuk dapat dipercaya dalam hal kehadiran dan penyelesaian kerja. (7). Initiative yaitu semangat untuk melakukan tugas - tugas baru dan dalam memperbesar tanggung jawabnya. (8). Personal Qualities yaitu menyangkut kepribadian, kepemimpinan, keramah tamahan dan integritas pribadi. Sedangkan pendapat Smith dikutip Maddatuan (2011: 40) menyatakan bahwa kinerja berhubungan dengan tiga aspek pokok, yaitu: (1) aspek perilaku menunjuk pada usaha-usaha yang dilakukan dalam upaya mencapai tujuan tertentu, dan perilaku individu memberikan hasil terhadap pekerjaan, (2) aspek hasil menunjuk pada aktivitas perilaku, dan (3) efektivitas organisasi menunjuk pada hasil kerja organisasi yang menekankan pada proses.Begitu juga hampir senada Pendapat Schuler dan Jackson dikutip Asnawi (2012: 45) menyatakan ada tiga jenis kriteria penilaian kinerja, yaitu (1) kriteria berdasarkan sifat, kriteria ini memfokuskan pada karakteristik pribadi seseorang kaaryawan, (2) kriteria berdasarkan perilaku, kriteria ini berfokus pada bagaimana pekerjaan itu dilaksanakan, kriteria ini penting bagi pekejaan yang membutuhkan antar personil, dan (3) kriteria berdasarkan hasil, kriteria ini berfokus apa yang dihasilkan.

Mengenai karyawan Hasibuan (2001:42) mengatakan bahwa karyawan adalah golongan masyarakat yang melakukan suatu pekerjaan dalam satu organisasi, baik kesatuan kerja pemerintah, maupun kesatuan kerja swasta. Pegawai adalah tetap pegawai yang menerima atau memparoleh penghasilan dalam jumlah tertentu secara teratur, selama pegawai yang bersangkutan bekerja penuh (full time) dalam pekerjaan tersebut. Selanjutnya adapun ketentuan yang berlaku untuk karyawan tetap adalah sebagai berikut : (1) tidak ada batasan jangka waktu lamanya bekerja. (2) hubungan kerja antara perusahaan dan karyawan kontrak dituangkan dalam " perjanjian kerja untuk waktu tidak tertentu" (3) perusahaan dapat mensyaratkan masa percobaan maksimal 3 bulan. (4) masa kerja dihitung sejak masa percobaan, dan (5) jika terjadi pemutusan hubungan kerja bukan karena pelanggaran berat maka karyawan tetap mendapatkan uang pesangon.Pendapat Drucker dikutip Maddatuan ( 2011: 49), menyatakan bahwa terdapat lima dimensi dalam mengendalikan kinerja karyawan, yaitu : (1) dimensi fisiologis, seorang akan bekerja dengan baik jika orang tersebut bekerja dengan berbagai konfigurasi operasional, yaitu bekerja dengan berbagai macam tugas dan ritme kecepatan disesuaikan dengan keadaan fisiknya, (2) dimensi psikologis, bekerja merupakan ungkapan kepribadian. Seseorang akan memperoleh kepuasan dari pekerjaannya dengan menampilkan kinerja yang lebih baik daripada mereka yang tidak menyenangi pekerjaannya, (3) dimensi sosial, yaitu bekerja adalah suatu ungkapan hubungan sosial diantara semua karyawan. Suasana konflik diantara karyawan dapat menurunkan kinerja, baik secara individu maupun kelompok, (4) dimensi ekonomi, yaitu imbalan jasa yang diperoleh dapat menghambat atau mendorong karyawan untuk berprestasi, dan (5) dimensi keseimbangan, dalam hal ini keseimbangan yang diperoleh dari pekerjaan dengan kebutuhan hidup akan memacu seseorang untuk bekerja lebih baik guna mencapai keseimbangan tersebut.

\section{Besarnya Kompensasi}

Setiap karyawan selalu mengharapkan imbalan yang cukup berdasarkan hasil kerja yang telah mereka berikan kepada perusahaan. Imbalan yang diberikan itu dapat digunakan oleh karyawan beserta keluarganya untuk memenuhi kebutuhan hidupnya. Pendapat Mathis dikutip Silaban (2011: 34) menyatakan bahwa nilai pertambahan hasil marjinal pekerja, merupakan 
nilai jasa yang diberikan pekerja kepada pengusaha. Sebaliknya upah yang dibayarkan oleh pengusaha kepada para pekerja sebagai imbalan terhadap jasa para pekerja yang diberikan kepada pengusaha. Menurut Nasution (1994:168) kompensasi adalah suatu program yang dilaksanakan perusahaan untuk dapat merangsang karyawan untuk meningkatkan produktivitas dalam proses produksi. Sedangkan kompensasi bagi perusahaan adalah merupakan pengeluaran dan biaya yang harus dibayarkan perusahaan kepada karyawan.Murlis (2000: 7) menyatakan bahwa gaji adalah sebagai bayaran pokok yang diterima karyawan, tidak termasuk tunjangan yang lainnnya. Upah dinilai dalam bentuk uang yang ditetapkan menurut suatu persetujuan dan peraturan dapat dibayar atas dasar perjanjian kerja antara yang memberi pekerjaan dan menerima pekerjaan.

Menurut Hasibuan (2001:168) mengemukakan kompensasi adalah semua pendapatan yang berbentuk uang atau barang langsung atau tidak langsung yang diterima karyawan sebagai imbalan balas jasa yang diberikan oleh perusahaan, sedangkan menurut Nawawi (2000:315) mengatakan kompensasi merupakan penghargaan atau ganjaran bagi para pekerja atau karyawan yang telah melakukan kontribusi dalam mewujudkan tujuannya melalui kegiatan yang disebut bekerja. Sementara itu menurut Martoyo (1994:124) pengupahan insentif dimaksudkan untuk memberi insentif yang berbeda, tetapi bukan didasarkan pada evaluasi jabatan, namun ditentukan pada produksivitas kerja. Peterson dan Plowman dalam Hasibuan (2001: 57) mengatakan bahwa orang mau bekerja karena : (a) the disire to live artinya keinginan untuk hidup merupakan keinginan utama dari setiap orang. Manusia bekerja untuk dapat makan dan minuman untuk dapat melanjutkan hidupnya, (b) the dissire for possesion artiny keinginan untuk memiliki sesuatu merupakan keinginan manusia yang kedua dan ini salah satu sebab mengapa manusia mau bekerja. (c) the disire for power artinya keinginan akan kekuasaan merupakan keinginan selangkah diatas keinginan untuk memiliki, mendorong orng yang mau bekerja, dan (d) the desire for recognation artinya keinginan akan pengakuan merupakan jenis terakhir dari kebutuhan dan juga mendorong orang untuk bekerja.

Siswanto (2003: 17), menyatakan bahwa kompensasi adalah imbalan yang diberikan oleh perusahaan kepada karyawan, karyawan telah memberikan sumban (tenaga dan pikiran) demi kemajuan perusahaan guna mencapai tujuan yang telah ditetapkan. Kompensasi mencakup semua pengeluaran yang diberikan oleh perusahaan untuk dinikmati oleh karyawan (Iskandarsyah, 2002: 103). Menurut Dessler (1994:440) jenis - jenis rencana insentif terbagi menjadi dua yaitu : (a) sport bonus (bonus ditempat) yaitu insentif yang diberikan secara spontan kepada karyawan atas pencapaian produktivitas kerja yang baik. Yang termasuk dalam sport bonus adalah, individual incentive programs (program insentiv individinsentif uindividual adalah suatu program yang memberikan pendapatan yang melebihi gaji pokok kepada karyawan yang telah memenuhi standar kerja individual. (b) variable pay ( pembayaran variabel) yaitu merupakan pemberian insentif yang didasarkan kepada produktivitas atau keuntungan perusahaan dan biasanya dibayar langsung atau sekaligus.

Umar (1999:16) mengatakan bahwa imbalan atau kompensasi yang diterima karyawan dibagi atas dua macam yaitu : (a) imbalan financial sesuatu yang diterima karyawan dalam bentuk seperti gaji / upah, bonus, premi, pengobatan, asuransi, dan lain - lain yang sejenis yang dibayar oleh organisasi. (b) imbalan nonfinancial, dimaksudkan untuk mempertahankan dalam jangka panjang seperti penyelenggaraan program - program pelayanan bagi karyawan yang berupaya untuk menciptakan kondisi dan lingkungan kerja menyenangkan seperti : program rekreasi, cafetaria, dan tempat berinbadat. Kompensasi tidak langsung disebut juga jaminan sosial program pelayanan karyawan atau program kesejahteraan karyawan.

\section{Disiplin Kerja}

Secara etimologi disiplin berasal dari bahasa latin disipel yang berarti pengikut. Seiring dengan berkembangnya zaman, kata tersebut mengalami perubahan menjadi disipline yang 
artinya kepatuhan atau yang menyangkut tata tertib. Menurut Mangkunegara,(2005:129) disiplin kerja dapat diartikan sebagai pelaksanaan manjemen untuk memperteguh pedoman - pedoman organisasi. Wursanto (1991:57) menyebutkan kedisiplinan adalah kesetiaan seseorang atau sekelompok orang pada aturan, norma - norma, intruksi - intruksi, yang dinyatakan berlaku untuk orang atau sekelompok tertentu. Menurut Hasibuan (2001: 213), disiplin adalah kesadaran dan kesediaan karyawan menerima semua aturan dan norma-norma yang berlaku diperusahaan. Selanjutnya dikatakan disiplin kerja adalah suatu sikap ketaatan pegawai terhadap suatu aturan atau ketentuan yang berlaku dalam suatu perusahaan atau organisasi atas dasar adanya kesadaran dan keinsafan bukan paksaan. Menurut Mukijat (1991:186) tujuan disiplin baik kolektif maupun perseorang adalah untuk mengarahkan tingkah laku pada realita yang yang harmonis. Menurut Handoko (2001: 209), menyatakan bahwa disiplin adalah kegiatan manajemen untuk melaksanakan stamdar kegiatan suatu perusahaan.

Untuk menciptakan kondisi yang harmonis terlebih dahulu harus diwujudkan keselarasan antara kewajiban dan hak karyawan sebagaimana pengertian disiplin dalam undang - undang No. 8 tahun 1974 yang dikutip oleh Siagian (2003:249) bahwa disiplin adalah kemampuan untuk mengendalikan dalam bentuk tidak melakukan sesatu tindakan yang tidak sesuai dan bertentangan danga sesuatu yang telah ditetapkan. Selanjutnya dikemukakan oleh Siagian bahwa displin adalah merupakan tindakan manajemen untuk mendorong semua karyawan guna memenuhi berbagai ketentuan yang berlaku diperusahaan. menurut Hasibuan (2001:213) didalam suatu organisasi terdapat beberapa indikator yang mempengaruhi tingkat kedisiplinan karyawan diantaranya ialah : (1) tujuan dan kemampuan, (2) teladan pimpinan, (3) balas jasa (gaji dan kesejahteraan), (4) keadilan, (5) pengawasan melekat, (6) sanksi hukuman, (7) ketegasan, dan (8) hubungan kemanusiaan.

Winardi (1993:218) membagi jenis disiplin kerja menjadi dua yaitu : (1) disiplin yang timbul dari dalam diri sendiri (self imposed discipline). Disiplin yang timbul dari dalam diri sendiri merupakan disiplin yang timbul atas dasar kerelaan, kesadaran, dan bukan atas dasar paksaan atau ambisi tertentu. Disiplin ini timbul karena seseorang merasa terpenuhi kebutuhannya dan merasa menjadi bagian dari organisasi, sehingga orang akan tergugah hatinya untuk sadar dan secara sukarela mematuhi segala peraturan yang berlaku. (2) disiplin berdasarkan perintah (command disciplin) disiplin ini timbul dan tumbuh disebabkan karena paksaan atau ancaman orang lain. Selanjutnya dikatakan disiplin kerja karyawan dipengaruhi oleh faktor - faktor berikut : (1) para pekerja datang ke kantor dengan tertib, (2) berpakaian rapi, (3) menggunakan perlengkapan kantor dengan hati - hati, (4) mengikuti cara kerja yang ditentukan oleh perusahaan, dan (5) memiliki tanggung jawab yang tinggi.Menurut Widjaya (2001: 29), menyatakan bahwa karyawan harus mentaati segala peraturan yang diterapkan perusahaan dengan penuh kesadaran dan tanggung jawab. Berdasarkan pembahasan di atas maka, yang dimaksud denga disiplin kerja adalah : suatu aturan yang telah diterapkan dengan harapan untuk mencapai tujuan yang baik.

\section{METODE}

Penelitian ini merupakan penelitian survei. Variabel terikatnya kinerja karyawan, variabel bebas besarnya kompensasi dan disiplin kerja. Subjek penelitian sebanyak50 orang karyawan PT. Lifes Good yang diambil secara acak, pengumpulan data menggunakan skla likert. Keabsahan data diperoleh dengan uji validitas dan uji reliabilitas. Berdasarkan hasil uji normalitas pada tingkat $\alpha 0.05$ subjek penelitian memiliki distribusi normal. Analisis data spss. 
Keterangan :

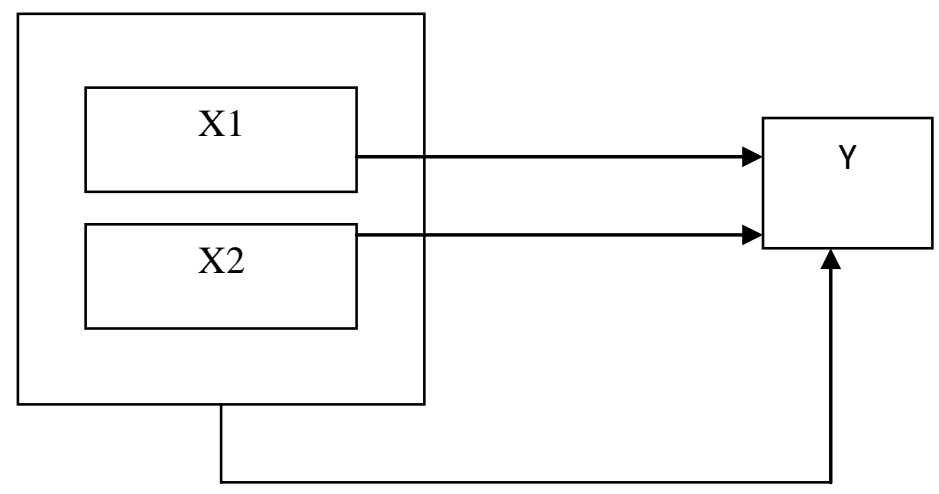

Gambar 1. Konstalasi penelitian

$\mathrm{Y}=$ Kinerja karyawan

$\mathrm{X} 1=$ Besarnya kompensasi

$\mathrm{X} 2=$ Disiplin kerja

\section{HASIL DAN PEMBAHASAN}

Selanjutnya dalam menguji penelitian ini, tahapannya adalah melakukan uji Linearity. Adapun hasilnya sebagai berikut:

Tabel. 1

Uji Linearity Persamaan Regresi Pemberian Kompensasi Terhadap Kinerja Karyawan

Anova Table

\begin{tabular}{lrrrrr}
\hline & Sum Of Squares & \multicolumn{1}{c}{ Df } & Mean Squares & \multicolumn{1}{c}{ F } & \multicolumn{1}{c}{ Sig } \\
\hline KinerjaKompensasi & 3712.034 & 27 & 204.902 & 3.698 & .000 \\
Linearity & 3926.578 & 1 & 3926.578 & 79.750 & .000 \\
Deviation From Linearity & 701.832 & 26 & 58.135 & .865 & .705 \\
Within Goups & 6753.891 & 206 & 39.528 & & \\
\hline Total & 6917.074 & 349 & & & \\
\hline
\end{tabular}

Kriteria pengujian nilai sig $0,705>0,05$ berarti persamaan regresi pemberian kompensasi terhadap kinerja karyawan adalah linier.

Tabel. 2

Uji Linearity Persamaan Regresi Disiplin Kerja Terhadap Kinerja Karyawan

Anova Table

\begin{tabular}{lrrrrr}
\hline & Sum of Squares & \multicolumn{1}{c}{ Df } & Mean quares & \multicolumn{1}{c}{$\boldsymbol{F}$} & \multicolumn{1}{c}{ Sig. } \\
\hline Kinerja Disiplin & 3091.325 & 25 & 387.115 & 2.901 & .000 \\
Linearaity & 3637.174 & 1 & 3637.174 & 42.875 & .000 \\
Deviation From & 3328.708 & 24 & 28.574 & .768 & .705 \\
Linearity & & & & & \\
Within Groups & 4380.401 & 139 & 234.409 & & \\
\hline Total & 6592.097 & 157 & & & \\
\hline
\end{tabular}


Kriteria pengujian nilai sig sebesar 0,705>0,05 berarti persamaan regresi disiplin kerja terhadap kinerja karyawan adalah linier.

Tabel. 3

Uji T

coefficients $^{\mathrm{a}}$

\begin{tabular}{lrrrrrrr}
\hline \multicolumn{1}{c}{ Model } & $\begin{array}{c}\text { Unstandardized } \\
\text { Coefficiens }(\boldsymbol{B})\end{array}$ & $\begin{array}{c}\text { Std } \\
\text { Error }\end{array}$ & Beta & \multicolumn{1}{c}{$\boldsymbol{t}$} & Sig. & Toletance & Vif \\
\hline 1 (Constat) & .619 & .451 & & 3,072 & .000 & & \\
Kompensasi & .343 & .348 & .415 & 3,506 & .000 & .351 & 1,204 \\
Disiplin & .398 & .329 & .558 & 3,872 & .001 & .438 & 1,763 \\
\hline
\end{tabular}

Besarnya kompensasi berpengruh secara signifikan terhadap kinerja karyawan.

Kriteria pengujian: Nilai $\mathrm{t}_{\text {hitung }}=3,506>$ dari nilai sig $=0.000$ pada @ 0.05.

Disiplin kerja berpengaruh secara signifikan terhadap kinerja karyawan.

Kriteria pengujian : Nilai $t_{\text {hitung }}=3,872>$ dari dan nilai sig $=0.001$ pada @ 0.05 .

Tabel 4

ANOVA $^{\mathrm{b}}$

\begin{tabular}{llrrrrr}
\hline & Model & Sum of Squares & \multicolumn{1}{c}{$\boldsymbol{d f}$} & Mean Square & $\boldsymbol{F}$ & \multicolumn{1}{c}{ Sig. } \\
\hline 1 & Regression & 3,059 & 3 & 1,874 & 37,602 &, 000 \\
\hline & Residual & 3,815 & 39 & 072 & & \\
\hline Total & 4,527 & 38 & & & \\
\hline
\end{tabular}

Besarnya kompensasi dan disiplin kerja secara bersama- sama berpegaruhsecara signifikan terhadap kinerja karyawan

Kriteria pengujian: Nilai $F_{\text {hitung }}=37,602$ dari nilai sig $=0.000$ pada @ 0.05 .

Tabel. 5

Koefisien determinasi Model Summary ${ }^{\mathrm{b}}$

\begin{tabular}{crrrrrr}
\hline Model & $\boldsymbol{R}$ & & $\boldsymbol{R}$ Square & Adjustec R Square & $\begin{array}{l}\text { Std Error of } \\
\text { The Estimate }\end{array}$ & Durbin-Watson \\
\hline 1 &, 806 &, 643 &, 718 &, 5219 & 3,761 \\
\hline
\end{tabular}

a.Predictors (Constant). Besarnya kompensasi. Disiplin kerja

b.Dependent Variabel. Kinerja karyawan

Nilai koefisien determinasi $(\mathrm{R})^{2}$ sebesar 0,643 artinya $64,3 \%$ besarnya kompensasi dan disiplin kerja mempunyai hubungan yang kuat terhadap kinerja karyawan, sedangkan sisanya $35,7 \%(100 \%-64,3 \%)$ tidak dianalisis dalam penelitian ini.

\section{PEMBAHASAN}

\section{Besarnya kompensasi berpengaruh signifikan terhadap kinerja karyawan}

Sesuai hasil penelitian, dengan mengacu pendapat Hasibuan (2001:168), mengemukakan kompensasi merupakan pendapatan berupa uang atau barang secara langsung yang diterima karyawan sebagai imbalan dari perusahaan. sedangkan menurut Nawawi (2000:315), menyatakan kompensasi merupakan penghargaan yang diterima karyawan setelah karyawan melakukan tugasnya yang telah ditetapkan oleh perusahaan. 
Jadi karyawan dapat menerima gaji dari perusahaan setelah melaksanakan tugasnya dengan baik. Mengacu pendapat Nasution (1994:168), kompensasi merupakan suatu program yang dilaksanakan perusahaan untuk dapat merangsang karyawan dalam melaksanakan tugasnya guna meningkatkan kinerjanya. Dengan mengacu pendapat Saladin (1997:37), menyatakan bahwa kinerja karyawan adalah hasil kerja baik secara kualitas dan kuantitas yang dicapai oleh karyawan setelah melaksanakan tugasnya sesuai dengan tanggung jawab yang diberikan kepadanya. Untuk ituperusahaan perlu memberi gaji yang cukup kapada karyawan sehingga karyawan selalu berusaha untuk meningkatkan kualitas pekerjaannya sesuai tujuan yang telah ditetapkan perusahaan.

\section{Disiplin kerja berpengaruh signifikan terhadap kinerja karyawan}

Sesuai hasil penelitian, dengan mengacu pendapat Hasibuan (2001: 213), menyatakan bahwa disiplin merupakan kesadaran dan kesediaan karyawan menerima semua aturan dan norma-norma yang berlaku diperusahaan. Selanjutnya dikatan indikator yang mempengaruhi tingkat kedisiplinan karyawan yaitu teladan pimpinan dan kesejahteraan karyawan. Menurut Mukijat (1991:186),tujuan disiplin adalah untuk mengarahkan tingkah laku karyawan. Disiplin ini timbul karena seseorang merasa terpenuhi kebutuhannya dan merasa menjadi bagian dari organisasi, sehingga orang akan tergugah hatinya untuk sadar dan secara sukarela mematuhi segala peraturan yang berlaku. Dengan mengacu pendapat Smith dikutip Maddatuan ( 2011: 40) menyatakan bahwa kinerja berhubungan dengan tiga aspek pokok, yaitu: (1) aspek perilaku menunjuk pada usaha-usaha yang dilakukan dalam upaya mencapai tujuan tertentu, dan perilaku individu memberikan hasil terhadap pekerjaan, (2) aspek hasil menunjuk pada aktivitas perilaku, dan (3) efektivitas organisasi menunjuk pada hasil kerja organisasi yang menekankan pada proses.Mengacu pandangan Hersey dan Blanchard (2000: 181), menyatakan bahwa kinerja sebagai hasil yang telah dicapi karyawan dengan menggunakan alat. Untuk mncapai kinerja yang baik perusahaan perlu menyiapkan alat untuk mendukung terlaksnanya suatu pekerjaan, sehingga karyawan dapat melaksanakan tugasnya dengan disiplin dan penuh rasa tanggung jawab, sehingga tujuan perusahaan dapat dicapai dengan baik.

\section{Besarnya kompensasi dan disiplin kerja secara bersama-sama ber pengaruh signifikan terhadap kinerja karyawan}

Sesuai hasil penelitian, mengacu pendapat Nasution (1994:168) menyatakan bahwa kompensasi merupakan suatu program yang dilaksanakan perusahaan untuk dapat merangsang karyawan dalam meningkatkan produksivitasnya. Sedangkan kompensasi bagi perusahaan adalah merupakan pengeluaran dan biaya yang harus dibayarkan perusahaan kepada karyawan.Dengan mengacu pendapat Siswanto (2003: 17) menyatakan bahwa kompensasi merupakan diberikan oleh perusahaan kepada karyawan, karena karyawan telah memberikan tenaga dan pikirannya untuk kemajuan perusahaan. Mengacu pendapat Murlis (2000: 7) menyatakan bahwa gaji adalah sebagai bayaran pokok yang diterima karyawan. Gaji dinilai dalam bentuk uang yang ditetapkan menurut suatu persetujuan dan peraturan dapat dibayar atas dasar perjanjian kerja antara yang memberi pekerjaan dan menerima pekerjaan.Widjaya (2001: 29) menyatakan bahwa karyawan harus mentaati segala peraturan yang diterapkan perusahaan dengan penuh kesadaran dan tanggung jawab.Winardi (1993:218) menyatakan bahwa disiplin dapat timbul dari dalam diri sendiri karena seseorang merasa terpenuhi kebutuhannya dan merasa menjadi bagian dari organisasi, sehingga orang akan tergugah hatinya untuk sadar dan secara sukarela mematuhi segala peraturan yang berlaku diperusahaan.MengacuPendapat Drucker dikutip Maddatuan (dalam jurnal manajemen, 2001: 49) menyatakan bahwa seseorang akan memperoleh kepuasan dari pekerjaannya dengan menampilkan kinerja yang lebih baik daripada mereka yang tidak 
menyenangi pekerjaannya.Menurut Hersey dan Blanchard (2000: 181) menyatakan bahwa kinerja sebagai hasil yang telah dicapi karyawan dengan menggunakan alat, dengan menggunakan alat yang tepat, maka kinerja karyawan menjadi lebih baik.

\section{SIMPULAN}

Hasil pengolahan data diperoleh nilai $t_{\text {hitung }}=3,506>$ dari nilai sig $=0,000$ pada $\alpha$ 0,05artinya besarnya kompensasi berpengaruh signifikan terhadap kinerj karyawan. Begitu jugahasil pengolahan data diperoleh nilai $t_{\text {hitung }}=3,872>$ dari nilai sig $=0,001$ pada @ 0,05artinya disiplin kerja berpengaruh signifikan terhadap kinerja karyawan. Dan Hasil pengolahan data diperoleh nilai koefisien determinasi $(\mathrm{R})^{2}$ sebesar 64,3\% artinya besarnya kompensasi dan disiplin kerja mempunyai hubungan yang kuat terhadap kinerja karyawan.

\section{DAFTAR RUJUKAN}

Asnawi, T. ( 2012). Pengaruh Budaya Organisasi, Kompetensi Dan Komitmen Pegawai Terhadap Kepuasan Kerja Serta Implementasinya Terhadap Kinerja Pegawai Negeri Sipil. Jurnal Manajemen. 15 (1) : 42-49.

Cusway.(2002). Penilaian Kinerja dan Pengembangan Karyawan. Yogyakarta: Gadjah Mada University Prees.

Desler, Gary dan Agus, Dharmala.(1994). Manajemen Personalia. Jakarta: Erlangga.

Guritno, Bambang.(2005). Perilaku Kepemimpinan, Kepuasan kerja. Jakarta: JRBL

Hasibuan, Malayu, S.P.(2001). Manajemen Sumber Daya Manusia. Jakarta: PT.Gunung Agung.

Hersey, Paul dan Blanchard. (2000).Management of Organizational Behavior, Utilizing Human Resorces. New Jersey: Prentice-Hall.

Handoko, T. Hani.(2001).Manajemen Personalia dan Sumber Daya Manusia. Yogyakarta:BPFE.

Iskandarsyah.(2002).Pengantar Ekonomi Mikro \& Makro. Jakarta: Ghalia Indonesia.

Maddatuan. (2011). Pengaruh Gaya Kepemimpinan, Budaya Organisasi Dan Motivasi Kerja Terhadap Kinerja Karyawan Dinas Pendidikan. Jurnal Manajemen. 15 (1) : 47-59.

Mathis, Robert L dan Jhon H Jackson. (2002).Manajemen Sumber Daya Manusia. Jakarta: Salemba Empat.

Mukijat.(1991). Latihan dan Pengembangan Sumber Daya Manusia. Bandung: Mandar Maju.

Murlis.(2000). Mengukur Kinerja Pelayanan dan Kepuasan Konsumen.Bandung: Pustaka Reka Cipta.

Mangkunegara, Anwar Prabu.(2005). Manajemen Sumber Daya Manusia Perusahaan. Bandung: Remaja Rosdakarya.

Martoyo, Soesilo. (1994). Manajemen Sumber Daya Manusia.Yogyakarta: BPFE.

Nawawi dan Hadari.(2000). Manajemen Sumber Daya Manusia, Untuk Bisnis KomPetitif. Yogyakarta: Gadjah Mada Universitas Press.

Nasution, Mulia.(1994). Manajemen Personalia. Jakarta: Erlangga.

Saldin.1997. Intisari Pemasaran dan Unsur-Unsur Pemasaran. Bandung: Linda Karya.

Silaban, P.(2011). Analisa Pengaruh Sistem Kompensasi Dan Kesempatan Promosi Terhadap Kinerja Karyawan Dengan Kepuasan Kerja Sebagai Mediasi. Jurnal Manajemen. 15 (1) : 33-46.

Siagian, Sondang P.(2003). Filsafat Administrasi. Jakartra: Gunung Agung.

Siswanto, Sutojo. (2003). Meningkatkan jumlah dan Mutu Pelanggang. Jakarta: Damar Mulia Pustaka.

Suprihanto, Jhon.2000. Penilaian Kinerja dan Pengembangan Karyawan.Yogyakarta: Gadjah Mada University Press. 


\section{sosio e-kons}

Volume 12, No. 1, April 2020, pp. 50-59

e-ISSN: 2502-5449

p-ISSN: 2085-2266

DOI : 10.30998/sosioekons.v12i1.5651

Umar, H.(1999). Manajemen Sumber Daya Manusia Dalam Organisasi. Jakarta: Gramedia Pustaka Utama.

Whitmore, J.1997. Coaching for Performance, alih bahasa Y Dewi Helly Purnomo. Jakarta: Gramedia Pustaka Utama.

Winardi. (1993). Manajemen Pemasaran. Bandung: Ramadhan.

Wursanto, I.G. (1991). Dasar-dasar Manajemen Personalia. Jakarta: Pustaka.

Widjaya. (2001). Perilaku Organisasi. Yogyakarta: BPFE. 